ОДИНЦОВА Мария Владимировна,

канд. филол. наук, доцент кафедры рекламы, связей с общественностью и лингвистики Московского энергетического института (г. Москва).

Электронная почта: nosovamv@mpei.ru

НАЗАРЕНКО Анна Александровна,

старший преподаватель кафедры рекламы, связей с общественностью и лингвистики Московского энергетического института (г. Москва).

Электронная почта: nazarenkoaa@mpei.ru

ЛЫОНГ Ба Винь,

магистрант Московского инженерно-физического института (г. Москва).

Электронная почта: lbavinh@gmail.com

\title{
Некоторые трудности вьетнамских студентов при изучении формул русского речевого этикета
}

УДК 811.161 .1

русский язык как иностранньй (РКИ), вветнамский, речевой этикет, ошибки, обращение
DOI https://doi.org/10.24866/2542-1611/2021-3/132-136

В статье представлен сопоставительный анализ речевых формул двух контактирующих языков, рассмотрен ряд отличий русского и вьетнамского речевого этикета. Проведен анализ типичных ошибок, возникающих в речи вьетнамских студентов вследствие межъязыковой интерференции. Выявлены следующие факторы влияния родного языка на русский: несовпадение ряда речевых клише, наличие местоимений вьетнамского языка, происходящих от терминов родства и определяющих выбор формы обращения на русском языке, национальная форма обращения, неиспользование сослагательного наклонения во вьетнамском языке в прагматических целях для выражения желания, вопроса, совета.

Формулы речевого этикета играют важную роль в сфере делового и межличностного общения. Этикетные формулы - языковые универсалии. В любом языке мира есть такие контактоустанавливающие слова, как здравствуйте или до свидания, познакомьтесь и др. Несмотря на то что значение этикетных слов и формул десемантизируется, они продолжают выполнять свою важную социальную функцию. Так, например, слово здравствуйте уже давно потеряло свое первоначальное значение «пожелание здоровья», но войти в аудиторию, где идут занятия, и не поздороваться, считается грубым нарушением этикета. Следует отметить, что во многих языках в силу широкой употребительности стирается собственное значение слов, входящих в состав речевых формул этикета, они становятся в первую очередь именно формулами, употребление которых фиксируется во всех сферах речевого общения [1].

Н.И. Формановская пишет, что «несмотря на то, что речевой этикет представляет собой социально-культурную универсалию, то есть свойствен всем народам, языкам и культурам, в каждой стране обычаи употребления речевого этикета национально специфичны» [2, с. 97]. Сориентироваться в специфике русской речевой традиции вьетнамским студентам помогают лингвострановедческие материалы на уроках РКИ, 
связанные с разъяснением национальных различий в речевом этикете.

Правила языкового поведения коренных носителей русской и вьетнамской культур во многом схожи, но имеется и ряд различий, которые могут в определенных ситуациях затруднить коммуникацию.

Набор этикетных формул разнообразен и обширен как в русском, так и во вьетнамском языке. Основан он на универсальном принципе вежливости (принцип соответствия речевой ситуации), при котором учтены такие параметры, как обстановка общения (официальная / неофициальная) и фактор адресата (социальный статус, личные заслуги, возраст, пол, степень знакомства).

Непосредственное отношение к нормам речевого этикета имеет обращение. Адресный характер вьетнамской речи отражается в весьма витиеватой и сложной системе вьетнамских местоимений, выбор которых зависит от взаимоотношений говорящего и слушающего, степени их родства, социального статуса, разницы в возрасте не только говорящего и слушающего, но и разницы в возрасте слушающего и родителей говорящего. Во вьетнамском языке при обращении к незнакомым людям принято использовать местоимения. Так, обращение мужчина к незнакомому человеку мужского пола в русском языке может употребляться самостоятельно, а во вьетнамском языке необходимо выбрать одно из местоимений chú / bác / ông (младший дядя по отиу = мужчина такого же возраста, как отеи / некто старше родителей / дедушка), которое будет находиться в структуре предложения, станет его членом. При обращении к незнакомой женщине, которую говорящий считает старше себя, во вьетнамском языке используется лексема chị (сестра).

В связи с тем, что местоимения вьетнамского языка происходят от терминов родства, при дословном переводе может возникать непонимание. Например, в случае если слушающий старше говорящего на 10-15 лет, местоимение вы может быть переведено на вьетнамский либо вокативами anh / chị (браm, сестра), либо со̂/chú (тетя/дядя), а местоимение $я$ в этой ситуации может быть переведено как em / cháu (младший брат или младшая сестра / внук, племянник, племяннииа). Такая сложная система местоимений вьетнамского языка приводит к тому, что во избежание путаницы студенты стараются не пользоваться в общении на русском языке собственно обращениями девушка, молодой человек, женшина, мужчина, используя в диалогах контактоустанавливающие обезличенные вежливые формы типа извините, простите и др.

Так как русские местоимения не имеют фиксированного употребления в межличностном общении, вьетнамские студенты отмечают, что им трудно уловить момент перехода в общении на $m$ ь. В результате нередко мы слышим обращение вьетнамского студента к одногруппнику на $b \boldsymbol{l}$, что в российской молодежной среде не является нормой.

Требует корректировки и форма обращения вьетнамских студентов к российскому преподавателю. Руководствуясь национальными принципами коммуникации, они нередко начинают диалог с обращения преподаватель (cô), в то время как традиционной формой в России является обращение к учителю, преподавателю по имени-отчеству. Форма обращения (cô) во вьетнамской культуре призвана подчеркнуть степень уважения к этому виду профессии, поэтому студенты часто чувствуют неловкость, вынужденно избегая употребления данного обращения. 
Трудность в обучении вьетнамских студентов этикетной лексике связана и с использованием отдельных лексем тематических групп приветствия и прощяания.

В русском языке существует несколько формул приветствия, имеющих аналоги во вьетнамском языке. При этом нашим трем формулам приветствия доброе утро, добрый день, добрый вечер соответствуют четыре во вьетнамском языке Chào buổi sáng (Доброе ympo), Chào buổi trua (Добрый «полденъ»), Chào buổi chiêu (Добрый «после полдня» (c 14.00 до 17.00)), Chào buổi tối (Добрый вечер). В связи с тем, что речевые клише не всегда совпадают при переводе, в речи вьетнамских студентов возникают ошибки типа Жду тебя в три часа вечера.

Разнообразные формы прощания в русском речевом этикете, такие как всего хорошего, всего доброго, пока и др. имеют один эквивалент во вьетнамском языке Tạm biệt, употребляющийся в формальных и неформальных ситуациях.

Ряд ошибок в речи вьетнамских студентов связан с неразличением таких слов, как не за что, пожалуйста, ничего. Это связано с тем, что во вьетнамской речи на выражение благодарности cảm ơn (cnacuбo) нужно отвечать không có gi (đâu) и на извинение xin lỗi! (извините) речевой этикет требует того же клишированного ответа không có gi (đâu). Дословный перевод фразы không có gì (đâu) - ничего, что нередко приводит к смешению этикетных формул, и в результате ответной репликой на спасибо можно услышать от вьетнамского студента ничего.

Отсутствует во вьетнамском языке так широко распространённое в русском языке использование сослагательного наклонения в прагматических целях для выражения желания, вопроса, совета. Прагматическое употребление в данном случае призвано смягчить сообщение о намерениях говорящего или ослабить категоричность утверждения или вопросительной формулы.

Используются данные формы при глаголах, обозначающих разного рода речевые акты: сказал бы, попросил бы, объяснил бы. Я попросил бы Вас говорить тише. (Я прошу Вас говорить тише - Тôi yêu câu bạn nói nhỏ lại (Тôi - официальное местоимение я, когда обращение не персонализировано, например, на выступлениях перед группой людей). В этой ситуации отдается предпочтение просьбе в форме вопроса. $B b$ можете говорить тише? - Bạn có thể nói nhỏ lại được không? (местоиме-

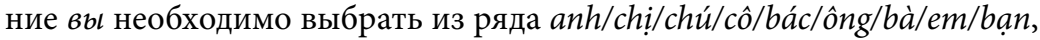
как отмечалось выше).

Прагматическое сослагательное наклонение встречается и в речевых формулах русского языка, содержащих модальные глаголы хотел бы, хотелось бы, мог бы и др. Я хотел бы поговорить с Вами (То̂ं тио̂́n nói chuyện với bạn - Я хочу поговорить с Вами.)

Выполняют побудительные функции и формы сослагательного наклонения с отрицанием, произнесенные с вопросительной интонацией. Не могли бы вы перезвонить позже? (Вы можете перезвонить nозжe? - Bạn có thể gọi lại sau được không? (bạn-дpyz, có thể-мoчb, gọi lại sau-nерезвонить, được không-или нет))

Значение оптативности также характерно и для сослагательного наклонения с инфинитивом. Неплохо бы сегодня пообедать. (Будет хорошо, если мы сможем пообедать - Sẽ thật tuyệt nếu chúng ta có thể cùng ăn truia (sẽ-будет, thật tuyệt-хорошо, nếu-еслu, chúng ta-мbl, có thểмочb, cùng-вместе, ăn trua-nooбedamb)) 
Не свойственна вьетнамской речи и общевопросительная конструкция с отрицанием, выражающая побуждение. В русском же языке часто встречаются вопросительные формы, сопровождаемые отрицательными частицами: не хочешь ли ты чаю? (Хочешь чаю? Bạn muốn uống trà không? (bạn-dpyz, muốn-xomemb, uống-numb, trà-чaŭ, không-или нет (слово không (нет) как ключевое слово обозначает вопрос во вьетнамском языке)). Используя подобные формулы на русском языке, говорящий смягчает высказывание, как бы предлагая при этом свободу выбора, альтернативу.

Приведенные выше примеры использования сослагательного наклонения, не свойственного вьетнамскому речевому этикету, говорят о том, что форма сослагательного наклонения в стереотипных формулах русского речевого этикета не переводит действие из реального в нереальное. Она лишь подчеркивает степень вежливости, снимая при этом излишнюю категоричность.

Освоение русского речевого этикета - важная составляющая в изучении самого языка и его культуры. Именно речевой этикет позволяет установить контакт с собеседником, чтобы состоялась коммуникация, и если она проходит в соответствии с существующими речевыми нормами, то это залог взаимопонимания. Бережное отношение к правилам русского речевого этикета и знание этикетных формул делают речь иностранца, говорящего на русском языке, выразительной и понятной и облегчают понимание речи носителей русского языка.

\section{Литература}

1. Резниченко Е.В. Национально-культурная специфика употребления некоторых формул русского речевого этикета (семантические изменения в русских этикетных формулах) // Картина мира через призму китайской и белорусской культур : сб. ст. междунар. науч.-практ. конф.,

Минск, 6 декабря 2019 г. / Белорусский государственный экономический университет; редкол.: М. В. Мишкевич (гл. ред.) [и др.]. Минск : Колорград, 2020. С. 92-97. 2. Формановская Н.И. Русский речевой этикет: лингвистический и методический аспекты М.: КомКнига, 2006. 158 с. 


\section{Maria V. ODINTSOVA,}

Ph. D. (in Philology), Associate Professor, Department of Advertising, Public Relations and Linguistics, Moscow Power Engineering Institute (Moscow, Russia).

E-mail: nosovamv@mpei.ru

Anna A. NAZARENKO,

Senior Lecturer, Department of Advertising, Public Relations and Linguistics, Moscow Power Engineering Institute (Moscow, Russia).

E-mail: nazarenkoaa@mpei.ru

LYONG Ba Vinh,

undergraduate student of the Moscow Engineering Physics Institute (Moscow, Russia).

E-mail: lbavinh@gmail.com

\section{Some Difficulties of the Vietnamese Students while Studying the Formulas of Russian Speech Etiquette}

UDC 811.161.1

mistakes,

speech etiquette,

Russian as a foreign

language (RFL),

Vietnamese,

address

The publication is based on a presentation at an international online conference "70th

anniversary of Vietnamese-

Russian relations in the field of science and education"

(Octobre 19, 2020) Hanoi,

Vietnam.
DOI https://doi.org/10.24866/2542-1611/2021-3/132-136

The article presents the comparative analysis of speech formulae of the two contacting languages, it considers several differences in the speech etiquette in the Russian and Vietnamese languages. It presents some typical mistakes occurring in the speech of Vietnamese students due to the interlanguage interference. It reveals the following factors influencing the native language upon the Russian language: the discord of some speech clichés, the presence of pronouns in the Vietnamese language, arising from the terms of relationship and determining a choice of addressing forms in the native language, the national form of addressing, not using the subjunctive mood in Vietnamese language pragmatically to express a wish, a question, an advice.

For citation: Odintsova M. V. Nazarenko A. A. Lyong Ba Vinh. Some Difficulties of the Vietnamese Students while Studying the Formulas of Russian Speech Etiquette // Oriental Institute Journal. 2021. № 3. P. 132-136. DOI https://doi.org/10.24866/2542-1611/2021-3/132-136

\section{References}

1. Reznichenko E.V. Natsional'nokul'turnaya spetsifika upotrebleniya nekotorykh formul russkogo rechevogo ehtiketa (semanticheskie izmeneniya v russkikh ehtiketnykh formulakh) // Kartina mira cherez prizmu kitajskoj i belorusskoj kul'tur : sb. st. mezhdunar. nauch.-prakt. konf., Minsk, 6 dekabrya 2019 g. / Belorusskij gosudarstvennyj ehkonomicheskij universitet; redkol.: M. V. Mishkevich (gl. red.) [i dr.]. Minsk : Kolorgrad, 2020. S. 92-97.

2. Formanovskaya N.I. Russkij rechevoj ehtiket: lingvisticheskij i metodicheskij aspekty M.: KomKniga, 2006. 158 s. 